\title{
Jordan's King Hussein's Peace Initiative and the Treaty with Israel: Overcoming Domestic and Foreign Pressures
}

\author{
Jacob Abadi \\ The United States Air Force Academy, Colorado, USA
}

\begin{abstract}
The Wadi ‘Araba peace treaty which Jordan's King Hussein signed with Israel on October 26, 1994 became a target of criticism ever since it became known to the Jordanian public. Intense pressure was exerted on the Jordanian government to revoke the treaty even before its signature. The opposition to it reached its peak in the following year, when the tension in the holy sites in Jerusalem mounted. Given the persistence of the Arab-Israeli conflict and the fact that the Palestinian issue remained unresolved, it was clear that the King was aware of the potential danger of signing a peace accord with Israel, and that he was prepared to face criticism not only from the Arab states but also from nationalists, Islamists and Leftists all of whom disapproved of his decision. Yet the King remained undeterred and boldly carried on the discussions that culminated in the peace treaty's signature. Bearing in mind the fact the Egypt was the first country to sign a peace treaty with Israel it seemed as if there was little risk involved in the normalization process, and that the opposition to the treaty would soon subside. As it turned out, however, the pressure to abrogate it continues to mount.
\end{abstract}

Keywords: Israel; Jordan’s King Hussein; Wadi ‘Araba Peace Treaty

\section{Introduction}

The purpose of this paper is to explore the process that led to the conclusion of the peace treaty and the reasons for it. In addition, the paper will shed light on the opposition to the treaty and the way in which the King managed to reduce its impact. The paper's background provides an analysis of the King's contacts with Israel, which began in 1960, and it attempts to demonstrate how the King's decision was closely tied to his relations with the surrounding Arab countries and the Palestinians, in addition to domestic factors such as the impact of pressure groups and the state of the Jordanian economy. Furthermore, the paper will examine the immediate steps that encouraged the King to move toward peace with Israel such as his decision to abandon his claim to rule the West Bank on July 1988, following the Intifada which erupted in the previous year; the Madrid peace conference, which was held on 30 October 1991, and the Declaration of Principles that was signed between Israel and the PLO on September 13, 1994 and enabled the King to negotiate with Israel without a general Arab consent.

One of the immediate factors, which brought the King to sign the treaty, was the fact that the Declaration of Principles was generally well received by the Jordanian public as the polls taken at that moment have demonstrated (Mitha, 2010, p. 5). On September 14, 1994, one day after the formal signing of the Declaration of Principles in Washington the two countries agreed on a common agenda, which cleared the way for a peace

Jacob Abadi, Professor, Department of History, The United States Air Force Academy. 
treaty. Undoubtedly, the treaty was beneficial for Jordan but it came at price, which included not only harsh criticism from Syria and other Arab countries who disapproved of its separate nature, but also from domestic groups such as the Muslim Brotherhood, Leftists and nationalists.

Undoubtedly, not all the treaty's terms were beneficial to Jordan. For example, according to the treaty, Jordan recovered its nominal sovereignty over territories occupied by Israel such as the Baqura and the Al-Ghamr, an area which extended over 344 kilometers that were occupied by Israel between 1968 and 1970. However, Jordan had to agree to additional 25 years of Israeli presence there. Many Jordanians criticized that term as a major concession on the King's part and a capitulation to the Israeli aggressor. Moreover, according to the treaty Jordan obtained Israel's recognition for its « special historical role » in Jerusalem, but this role was ill defined and critics later argued that the King's decision to disengage from the West Bank did not mean that he renounced his claims to the Islamic sites in Jerusalem. Other articles in the treaty provided for the establishment of diplomatic relations, open borders, economic cooperation and water allocation. The delicate question of the refugees of the Palestine War of 1948 was left for Israel and the PLO to negotiate, while the question of those who fled to Jordan during the Six Day War of 1967 was simply referred to a commission, which consisted of representatives from Israel, the PLO, Jordan and Egypt. In accordance with the peace treaty the two countries exchanged ambassadors, border posts were opened, Israeli tourists could visit Jordan, and the national Jordanian airline obtained the right to fly over Israeli airspace. Additional treaties on transportation, civil aviation, science, culture and communications were signed, and they set the stage of cooperation between the two countries. However, for the treaty's opponents there was little significance in these treaties since the entire accord did not address the main issues such as the refugees and the custodianship of the holy sites.

The opposition to the treaty gained momentum gradually and it reached its apogee by the end of the decade. Serious difficulties appeared in March 1999, following the Israeli decision to reduce the amount of water it pledged to transfer to Jordan. The outbreak of the Al-Aqsa Intifada in October 2000 and the subsequent rise of Ariel Sharon as Israel's prime minister strained the relations between the two countries even further and the opponents of the peace treaty intensified their criticism. The stalemate in the Israeli-Palestinian peace process which followed and the anger over Sharon's view that Jordan is a Palestinian state did not bring the two countries into a meaningful partnership. Nevertheless, the Jordanian government did not yield to the pressure to abrogate the treaty and King Abdallah II who ascended the throne in February 1999, does not seem inclined to alter the course taken by his father.

This paper analyzes the reasons for King Hussein's decision to begin the peace process however, in order to understand why he embarked on such bold initiative, it is necessary to trace his early contacts with Israel to the early years.

\section{The Early Years}

The euphoria which accompanied the Israeli-Jordanian peace treaty seems to have led commentators to underestimate the intensity of the conflict between the two countries in the early years. In the first place, the contacts which the leaders of Yishuv (the Jewish community in Palestine during the Mandatory period) had with Emir Abdallah enhanced the moderate and conciliatory image of the ties between the two countries to the point where the intensity and the hostility, which marked these ties in the first decade after the establishment of the Jewish state are downplayed. Attempting to trace the origins of the Israeli-Jordanian cooperation, commentators argued that the seeds for the Israeli-Jordanian cooperation were planted already during the 
Mandatory period and that they resulted from Britain's policy of partition and accommodation of the Jews and the Arabs who resided in Palestine and counted on British help against Arab nationalism (Bligh, 1998, p. 1). While there is substance in such arguments they tend to downplay the intensity and the acerbity of the conflict between two countries, which did not lessen until the late 1950s. Despite the contacts between the Zionist leaders and Emir Abdallah during the Mandatory period there were major obstacles that could hardly be overcome. In the first place, the Hashemite response to the Balfour Declaration of 1917 in which the British government agreed to facilitated the creation of a homeland for the Jews in Palestine was negative, and the members of the assembly who drafted Transjordan's National Covenant stated categorically that they regarded it as contradictory to the promise made to the Arabs and as a violation of international laws (Mādhā taraka al-amīr lil-asatīr, 1938, p. 129).

Another thorny issue that marred the relations between the two countries was the Zionist scheme to establish Jewish settlements in Transjordan. Conceived by the German Jewish entrepreneur Pinhas Ruthenberg, this plan was widely debated in British government circles and officials such as Herbert Samuel and Lord Reading viewed it with favor (Gelber, 1997, p. 51). However, the response from officials in Transjordan was fast and furious. For example, Shams al-Din Sami, one of the earliest proponents of Jordan's struggle for independence expressed his indignation over that plan in the harshest manner. At a meeting of the legislative assembly on June 4, 1929 he said that Ruthenberg's Plan was illegal and that it ought to be rejected outright by the government of Transjordan. ${ }^{1}$

Generally, the Hashemite regime was not inclined to accommodation with the Zionist leadership unless it was constrained by other factors. Pragmatic considerations brought the two countries to accept a status quo that served their interests at that moment. As it turned out, the status quo that followed the Palestine War of 1948 was convenient for Israel and Jordan who felt threatened by the national Palestinian movement. Both had good reasons to fear creation of an independent Palestinian state and therefore sought to suppress the movement. The fact that more than half of Jordan's inhabitants were Palestinians was a major cause of concern to the Hashemite regime, which feared that Jordan would turn into a Palestinian state, while Israel regarded the creation of a Palestinian state as a threat to its very existence. Most disquieting for the Hashemite regime was the claim, which the right-wing in Israel adhered to, that Jordan was essentially Palestinian and that therefore the Palestinian claim for a separate state had no validity. This claim not only gave legitimacy to a Palestinian takeover in Jordan, it also meant that Jordan was in danger of losing its unique Hashemite identity. The common interest which Israel and Jordan had in preventing the emergence of an independent Palestinian state provided a general strategic framework, which they both adhered to despite the disagreement on the borders, allocation of water and other issues. Neither Israel nor Jordan chose to announce or to document this tacit agreement and this is what kept the long border between the two countries relatively quiet until the Six Day War of 1967, despite occasional infiltration of Palestinian guerrilla fighters, which often irritated Israel, and caused it to retaliate by invading Jordanian territory.

While the King sought to keep the Palestinian population in his territory under control, Israel's remained occupied with state-building issues such the creation of an army, absorption of immigrants and the building of a national economy, and it was not until the Six Day War that the Arab-Israeli conflict began to loom large on the national agenda. Thus, the relations with Jordan remained on the back burner and were not discussed in public

\footnotetext{
${ }^{1}$ Details regarding his arguments are discussed in Fawzī al-Khutabā, Shams al-Dīn Sāmi: al-rajul, wa-al-tajrībah, wa-al-ru'yah, ('Ammān: Dār al-Manāhij, 2002, pp. 77-81).
} 
(Zaki, 2007, p. 73). All along, King Hussein's fear that his country would be taken over by Palestinians brought him to cultivate relations with the Bedouin tribes, which rather than being suppressed, were encouraged and gradually incorporated into the Jordanian government and bureaucracy, and thereby turned into the backbone of the Hashemite regime (Alon, 2001, p. 85).

That the tension between the two countries remained high in the early years was a consequence of the Hashemite fear that Israel intended to invade Jordan. Discussed frequently in Israeli government circles this was a possibility that the Hashemite regime could hardly ignore. Indeed, former Foreign Minister Moshe Sharett had noted in his memoirs that Israel's Prime Minister David Ben Gurion had seriously considered the idea of invading Jordan and occupying the country. This was in reaction to the attack on an Israeli bus at the Scorpion Pass (Ma'alei Akrabim) on the road between Eilat and Be'er Sheba, where 11 Israelis were killed on the night of 16-17 March 1954, and only four survived. Sharett rejected the idea as flashy and dangerous. He wrote to the Prime Minister:

I have heard that after Ma'alei Akrabim you have expressed an opinion that we ought to capture an area in Jordan. In my opinion, such step would have immediately brought us to war with Jordan, with England fighting on her side and the United States screaming and condemning us in front of the entire world, and treating us as aggressors. (Sharett, 1978, p. 436)

Indeed, the British thought of coming to Jordan's aid if war broke out between the two countries and had warned the Israelis to that effect (Yergin, 1992, p. 489).

Other issued marred the relations between the two countries in addition to the border incidents caused by infiltrating Palestinians into Israeli territory. Concern about Israel's intentions was not confined to territorial expansion but also to Israeli economic domination in the region, which could have adverse effect on the weak Jordanian economy. Indeed, such plans were discussed in Israeli government circles. Thus for example, in June 1954, Abraham Ruthenberg conceived of a plan to purchase the shares and the installations of the Israel Electrical Company in Jordan and to transfer the Jordanian part to the British Balfour-Beatty Company. Naturally, such scheme would have benefitted the Israeli and the British companies while excluding the Jordanians from the deal. Concerned that the Jordanian government would regard such act as interference by Israel and take measures against the company Sharett opposed the proposal. However, reluctant to abandon the plan, Ruthenberg opined that the Jordanian prime minister would be receptive to such plan. After a long debate Sharett agreed to implement the plan on the proviso that all means to achieve it were to be legal that both the British Exchequer the Foreign Office gave their consent (Sharett, 1978, pp. 530-531, 540). Naturally, these economic schemes were regarded with suspicion by the Hashemites and they seemed to confirm the Nasserite Pan-Arab claim that Zionism served as a tool of western imperialism that sought to dominate the downtrodden Arab inhabitants of the Middle East. Such claims resonated with many Jordanians who regarded Israel's intentions with suspicion.

Throughout the entire period water distribution remained an issue of major concern and a significant obstacle to normal relations between the two countries. In 1955, the American envoy Eric Johnston was sent by President Dwight Eisenhower with a proposal to divide the waters of the Jordan River between the two countries, but he faced enormous difficulties and negative response from the Arab states. Constrained by the paucity of water and the poor state of his country's economy the King opted for a pragmatic approach and sought to avoid conflict over the issue. Recalling the experience, Sharett recorded in his memoirs that despite 
Johnston's frustration the King was willing to listen. He writes:

Nevertheless, he found the King of Jordan- whose influence in his country is growing constantly-willing to listen to words of virtue, and to agree that hatred never solved any problem, and that real policy making requires a positive approach to problems affecting the destiny of multitudes of humans. (Sharett, 1978, pp. 530-531, 540)

Despite the tension along the border with Jordan and the official pronouncements that emanated from Amman the conviction that an accommodation with Jordan was a real possibility began to permeate in Israeli government circles. Convinced that peace with Jordan was a not a remote possibility Sharett noted in his memoirs:

Among all Jordanian statesmen there are 2-3 whose hearts are for peace with Israel, but there are those who believe the complete opposite. It all depends on the push that would come from the negotiations table on the water issue-whether it would lead to an agreement or to a messier dispute. (Sharett, 1978, p. 745)

The Israeli security doctrine adopted during the 1950s determined that the stability of the Hashemite regime was a strategic asset in the struggle against Arab radicalism sponsored and supported by Egypt and Syria. Despite the fact that the Jordanian regime was regarded as recalcitrant and unwilling to let Israelis an access to the holy sites, and despite the frequent violations of the truce, the Israeli government deemed it essential to defend the Hashemite regime against the threat of Pan-Arabism, the Egyptian-Syrian led Arab radicalism and the Palestinian national movement. In sum, the Israeli government could reasonably assume that the Hashemite regime, despite the verbal support and the freedom of action that it gave the Palestinians to operate against Israel from its territory, would collaborate with Israel in its main objective to combat Arab radicalism. Furthermore, Israeli strategists and government officials assume that the Hashemite regime would avoid a major Arab attack on Israel from its territory. Nevertheless, at no time did the Israeli government exclude the possibly of invading Jordan if the Hashemite regime collapsed and the King was well aware of that possibility. The Israeli government made it clear on numerous occasions that if the Hashemite regime collapsed it reserved the right to invade the West Bank and conquer it partially, or in its entirety. Thus for example, in one of his addresses to the government Ben Gurion informed its members that he told UN Secretary Dag Hammarskjöld:

They [the Jordanians] have no right whatsoever to Mount Scopus and the West Bank. You know that Jordan is an unstable state. I am not sure if it will survive. It is true that few of us say that it is necessary to conquer the West Bank [but] most of us think that we cannot afford to add another million Arabs who might destroy the State of Israel. (Zaki, 2007, pp. 78-79)

The intensity of Arab radicalism, which culminated in a union between Egypt and Syria known as the United Arab Republic (UAR) in 1958, brought home to the Hashemites the realization that an alliance with Israel was a sine qua non for Jordan's survival. This explains the reason for the onset of strategic talks, which senior Jordanian government officials held with their Israeli counterparts shortly afterwards. A British source quoted the head of Jordan's Intelligence saying that "an agreement with Israel is Jordan's only hope". Consequently, these contacts led the foundation of a wider understanding between the two countries, with a view to keep the status quo and to expand its dimensions (Zaki, 2007, p.80).

Although Israel's relations with Jordan lacked the acerbity which characterized its relations with Syria there were numerous moments of crisis during the 1950s. Tension along the Israeli-Jordanian border increased considerably in July 1956, when the Arab media reported on concentration of Iraqi forces on the Jordanian 
border. Although this was primarily done in an attempt to counter Egyptian influence in the Fertile Crescent, the Iraqi government justified it on the ground that it came to rescue Jordan from Zionist aggression. At the same time, the Arab media were replete with news regarding the concentration of Israeli forces on the Jordanian border. Having to respond to these rumors and fearing strong response by the Israeli government Sharett was bewildered and confused. He noted in his memoirs, "I am isolated and paralyzed and all I have to do is to eat my heart out" (Sharett, 1978, pp. 1540-1541). All along, Ben Gurion considered the possibility of invading Jordan. His conviction was that the collapse of Hashemite regime would inevitably lead to war since the neighboring Arab countries would rush to grab Jordanian territory, leaving Israel with no choice but to act (Sharett, 1978, p.1617).

Following the Israeli raid on the Palestinian city of Qalqilya on October 11, 1956 which caused many casualties, King Hussein asked the Iraqi government to send a division to Jordan. Infuriated at the King's appeal Israel's Foreign Minister Golda Meir told the Knesset members:

The entry of Iraqi units is part of a design aimed at promoting Iraqi territorial ambitions and bringing a drastic change in the status quo in the region. This constitutes a direct threat to Israel's territorial integrity on the part of an Arab state that invaded Israel in 1948, and then refused to sign the Armistice with it. Committed to its obligation to its people, the Israeli government is determined to face this threat. (Cited in Medzini, 1990, pp. 243-244)

Nevertheless, the Israeli government continued to regard the continuity of the Hashemite regime as an essential component of Israel's security and as a stabilizer in the region. This became abundantly clear following the coup, which brought General 'Abd al-Karim Qāsim to power in Iraq in 1958. The Israeli government agreed, albeit reluctantly, to let the British fly their troops and equipment through its air space in order to save the Hashemite regime from collapse. Qāsim's rise to power in Iraq, the turmoil in Jordan and the civil war in Lebanon necessitated a British intervention in Jordan and brought home to the Israelis the awareness that it was imperative to protect Hussein's regime. Likewise, the King who was concerned about the stability of his regime saw considerable value in semi-normal relations with Israel.

The conditions that prevailed in the late 1950s compelled King Hussein to keep on reassessing his policy. Jordan was not only engulfed by Arab enemies who did not hide their territorial ambitions but it was left without a major western power to support it. The Israeli-Jordanian collaboration emanated from the King's sense of isolation, which was intensified already in 1956, following the dismissal of Glubb Pasha the celebrated commander of the Arab Legion, and the British departure from his country. This was in response of intense pressure of pro-Nasserite groups and individuals, which the King could not contain during this era of intense pan-Arab outburst. Seeking an alternative source of western support the King saw Israel as a possible ally and a channel to Washington. This sense of insecurity, which intensified by the formation of the UAR and the spread of pro-Nasserite propaganda in Jordan left the King in a state of despair, and the only logical alternative was to establish military contacts with Israel.

Throughout the late 1950s and the early 1960s the Hashemite regime was besieged by numerous pro-Nasserites, Liberals, Islamists and other pressure groups and the King was compelled not only to ask for western help, but also to maintain a certain level of understanding with Israel. This explains his first approach to Israel in August 1960. Feeling isolated and threatened by the UAR and the tension along its border with Egypt the Israeli government welcomed the King's initiative. Moreover, the assassination of Jordan's Prime Minister Hazza' al-Majalli by Syrian agents at that month made the King conscious of his kingdom's 
vulnerability and brought him to seek military cooperation with Israel. This marked the beginning of what is estimated to have been more than five hundred hours of secret meetings which the King held with Israeli leaders, with the exception of right-wing opposition leader Menachem Begin. In one of his meetings with John H. Burns of the U.S. Foreign Service the King revealed that that he had met Golda Meir, Abba Eban and other Israeli politicians prior to the Israeli attack against the Palestinian guerrilla fighters who operated against Israel from his territory (Lyndon Johnson Administration Memorandum, 1966).

The military talks between the two countries, which begun in 1960 expanded further when Egypt, Syria and Iraq announced their decision to form a union and thereby caused street demonstrations in Jordan, which pressured the King to join it. At the same time, there was unrest in the West Bank, which not only threatened the stability of the Jordanian regime but also posed a threat to Israel's security. The subsequent deliberations among Egypt, Syria and Iraq regarding the establishment of yet another Arab union, in the spring of 1963, caused even greater alarm in Jordan and Israel. As Mamdouh Anis Fathi put it:

The negotiations regarding the tripartite unity in Cairo brought about a violent response in several countries the most important of which were Jordan and Israel. And in Jordan there were demonstrations demanding that the government take part in the unity negotiations in Cairo, and there were clashes and battles in which some were killed and others injured. Wasfi Tal's government resigned and Samir al-Rifa'i was entrusted with the formation of a new government in order to face the situation. And even more dangerous was [the fact] that the events in Jordan stirred Israel, which began concentrating several of its units on the border, and that complicated the situation further. (Fathi, 2003, p. 211)

This common concern brought the two counties to closer cooperation in April 1963. But the tension did not subside during the following two years. The Nasserite elements remained as vociferous as ever both in Jordan and outside. While his forces were trapped in the Yemeni quagmire Nasser intensified his anti-Israeli rhetoric and openly spoke about the destruction of the Jewish state. Tension along the Israeli-Syrian border mounted as well. Jordan remained the only pro-western Arab country in the region but it had no reliable western ally to count on. Consequently, King Hussein was compelled to act. This explains why he approached the Israelis again by the end of 1965. He specifically asked for a meeting with the Israeli representative Ya'acov Herzog who was then the head of Israel's Prime Minister's Office. Herzog communicated the message to the Israeli ambassador to Paris, Walter Eithan who arranged a meeting between King Hussein and Golda Meir in the house of a Jewish family in Paris in November that year. At the meeting the King expressed his concern about the precarious position of his country and the threats posed by Egypt, Syria and the PLO. He asked that the Israeli government give its consent to Jordan's purchase of tanks from the United States, which the Israeli government had already agreed to and he promised that they will not cross the Jordan River and never be used against Israel. Moreover, he agreed to provide US President Lyndon Johnson a written guarantee to that that effect and he promised that he will not sabotage Israel's efforts to expand its water projects. Seeking to obtain the King's good will Golda Meir agreed that Israel would abide by the terms of the Johnston Plan and refrain from pumping more water from the Jordan River than the amount agreed to. King Hussein had also asked that Israel exercise restraint and avoid retaliating against the Palestinian guerrilla fighters across the Jordanian border. He blamed Syria for encouraging the incidents along the border and asked that Israel understand his predicament (Medzini, 1990, p. 295).

What prompted King Hussein to expand the cooperation was also the realization that Israeli army was far superior to his own. This became abundantly clear after Israel carried out several retaliatory raids against Palestinians who operated from Jordanian territory. One of the most devastating raids was the one in Samu' 
which took place on November 13, 1966, and forced the King to reassess his position. What cemented the relationship further was the joint fear that Egyptian expansion in the Red Sea region posed threat to their port cities of Eilat and Aqaba.

Nasser's intervention in the Yemeni civil war, which began in 1962, posed a serious threat to these ports and thereby brought the countries to closer strategic collaboration (Bligh, 1998, p. 3).

\section{The Six Day War and after}

The possibility that Jordan would join the Syria and Egypt in a war against Israel seemed remote to many Israelis. Even the Syrians had their doubt. Thus for example, the founding member of the Ba'ath Party, Sami al-Jundi argued that the Syrians believed that Jordan will not enter the war in 1967 and that the conflict will end with Egypt and Israel exhausting each other until Syria would come to the rescue (Ajami, 1992). But the pressure of Arab radicalism was too intense for the King to ignore even though he was warned by the Israelis before the outbreak of the hostilities. Since the Samu' incident King Hussein cooperated with the Israelis by exchanging intelligence information about terrorists who operated in the West Bank and he sought to avoid further clashes, which could antagonize the Israelis. However, his fear on the eve of the Six Day War was that remaining outside of the conflict would antagonize not only the Palestinians and many officers in his army but also the Egyptians who could invade Jordan if Nasser won the war (Oren, 2002, p. 127).

Israel's victory in the Six-Day War of 1967 constituted a crushing defeat for Jordan, which lost the West Bank and East Jerusalem. Scores of American tanks were caught by the IDF in the West Bank during that campaign and the Israelis who hoped that the King would keep his promise to avoid war were disillusioned (Medzini, 1990). The impact of Israel's decision to annex East Jerusalem shortly afterwards was devastating for Jordan. Anwar al-Khātīb al-Tamīmī who was the governor of the Jerusalem district noted in his memoirs that the Jordanians were concerned about the impact of the Israeli annexation on the legal status of the holy places and the Islamic properties. He recalled how furious and frustrated the Jordanian officials were and how vigorously they protested. He writes:

We protested to the military governor general regarding the annexation of Jerusalem, which we refused to accept. We regarded Jerusalem as part of the West Bank, which constitutes a part of the Hashemite Kingdom of Jordan, and [we said] that the Israeli decision was in violation of the fourth paragraph of the second clause of the United Nation's Covenant. Those who were present announced that the inhabitants of Jerusalem had already exercised all their full rights to self-determination by declaring the unity of the two banks, based on the historical resolution that was adopted by the Jordanian parliament on April 24, 1950. (al-Tamīmī, 1989, p.179)

Following the Six Day War the Israelis began discussing the possibilities of reaching an agreement with the Arab states. Proposals to establish a joint Israeli-Jordanian confederation over the Palestinian territories began to emerge in earnest at that time. The notion that the Israeli-Palestinian conflict could be resolved through the establishment of a confederation resonated in the Israeli Labor Camp. Thus for example, Labor leader Shimon Peres writes:

The political logic of a functional compromise might lead us, in the framework of peace, to the concept of a confederation between "a Jewish Israel" and a "Palestinian Jordan"; the Jewish settlements in Judah and Samaria will have a special status, within Jordan. At the same time, the city of Gaza will have a special status. Under Israeli sovereignty united Jerusalem might be not only Israel's capital but also that of the confederation, while Amman will be the capital of Palestinian Jordan. (Peres \& Eshed, 1978, p. 257) 
Even the right-wing opposition leader Menachem Begin agreed to the idea of a confederation. However, he made it abundantly clear that all the Palestinians could hope for was 'home rule' or autonomy (Kimche, 1991, p. 251).

One of the most talked about peace plans was that of Yigal Allon the former celebrated commander the Palmach elite force of the Yishuv. The Allon Plan was based on the partition of the West Bank, or Judah and Samaria between Israel and Jordan. Almost all the cabinet members were willing to support the plan. Even Moshe Dayan who served as defense minister since the Six Day War did not rule out the possibility of sharing these territories with Jordan, even though he doubted that it could materialize. As it turned out, however, Allon's Plan was never brought to discussion at a cabinet meeting and prominent figures such as Menachem Begin, Joseph Sappir and others who had reservations about it had never had the opportunity to express their formal opposition to it (Bader, 1979, p. 204).

The encounter between Israel and Jordan during the Karamah Campaign of March 21, 1968 where Israel sought to hit Palestinian targets in Jordan ended in severe casualties for Israel. The Jordanian press celebrated the operation, paying homage to the commander who led the campaign. Thus for example, the weekly magazine Al-Sabil praised its commander Lieutenant General Mashhūr Ḥadītah al-Jāzi as the hero who obliterated the "legend" regarding the invincibility of the IDF (Al-Dhikrá al-sanawīyah, 2002, p. 63). Yet the astute King was not deceived by his own propaganda and did not lose his appreciation of his Israeli foe. Nor was he willing to put an end to the secret meetings or to forfeit the strategic alliance.

The attitude of the Israeli leaders toward a solution to the Arab-Israeli conflict and toward King Hussein underwent drastic changes over time. Even Dayan who promoted the 'open bridges' policy rejected King Hussein's demand that Israel withdraw from all the territories it conquered in the Six Day War. By 1973, he became a proponent of Greater Israel that would include Judea and Samaria. He made a statement to that effect in his press interviews and speeches. For example, in a speech at the ceremony on the peak of Masada he stated his conviction that Israel' victory in the war provided it the opportunity to redefine its borders, that Israel had a right to settle in the West Bank and that Israel's boundaries ought to extend from Jordan to the Suez Canal (Eban, 1977, p. 487). Yet, the King did not sever the contacts with Israel and during the Yom Kippur War of 1973 he managed to persuade the Israeli chief of staff to divert the artillery fire from a hill on the Golan Heights where the king was scheduled to address the troops that he sent to help Syria.

\section{The Right-wing in Israel and the "Jordan-Palestine" Equation}

While the Labor camp in Israel had its moderate vision of settlement with Jordan the right-wing took a different and more hard-line approach. In the eyes of the Israeli right-wing Jordan had no validity as an independent state. Since his early days as leader of the opposition Herut.

Party Begin was unwilling to recognize Jordan as a legitimate state and his party's organ with the same name had mentioned Jordan in quotation marks only. This was in line with the popular song of the Irgun paramilitary group, which he commanded prior to the establishment of the state of Israel and its slogan The Jordan River has two banks and both belong to us! But even Begin was compelled to reassess his position after he joined the National Unity Government on eve of the Six Day War. Following the Israeli victory he supported Dayan's "open bridge" policy with Jordan and he refrained from advocating the crossing of the Jordan River. Furthermore, he was aware of the meetings which the Israeli leaders of the Labor Party had with King Hussein and he did not make an attempt to discourage the King or to bring the contacts to an end. For 
Begin and his followers in the right-wing the separation between the east and the west banks of the Jordan River had to be maintained: Israel should not give up what it had and should not demand what it did not have. By the beginning of 1970, Begin shared Dayan's position, which opposed Soviet influence in Jordan and he even approved of the aid that Israel provided Jordan during Golda Meir's ministry. Jordan's name no longer appeared in quotation marks and when Begin came to power in 1977, he called upon the King to start peace negotiations (Naor, 1988, p. 40). Yet he remained suspicious and distrustful of the King's intentions.

Yitzhak Shamir who succeeded Begin as the Likud prime minister in 1983, adopted a similar attitude of suspicion and distrust toward the King and he insisted that Israel should not rush to conclude peace with him. In one of his speeches to the Knesset he said:

In my eyes it is extremely important to start negotiations with the leaders of the neighboring countries in matters of mutual concern. As for Hussein, for example, there are numerous topics requiring co-existence in our region; for example, the waters of the Jordan River. This is a gigantic problem... or the phosphate enterprise in the Dead Sea; we have a huge common resource here; or the ports of Eilat-Aqaba with their ecological problems, and other issues such as Jordan's outlet to the sea and its oil pipeline. These are the issues on which there is need to reach an agreement with Hussein in order to create and better atmosphere that would enable us to start negotiations on the main issues. Meanwhile, they only "grind water". Hussein keeps on expressing the most extreme position. They always ask what are we going to offer but it is always possible to ask what does he offer us?... It is better to start negotiations about coexistence because destiny determined that we live in the same region, close to each other, and sharing common problems. ( Naor, 1988, p. 37)

The way to obtain peace, according to Shamir was to convince the King that an accommodation with Israel would earn his country material and practical benefits such as technical assistance and economic prosperity. Such attitude triggered a critical response from many who did not approve of his cavalier attitude and his expectation that the King would come to the negotiation table without conditions or territorial concessions. Thus for example, the Likud's former secretary Arye Naor had noted in his critical book, Writing on the Wall:

The assumption that it is possible to negotiate with Jordan in an inverted order reflects total disregard to reality. We cannot hope to reach a set of international agreements with Jordan prior to the conclusion of a peace treaty. It is necessary that Jordan agree to that and there is need for Arab legitimacy to such step. Whoever thinks that if we maintain a stubborn position and show determination, without weakness and without submission, God forbid, Hussein would be appeased, does not treat Jordan and its needs seriously, and does not base his policy on reality but on delusion. (Al-Dhikrá al-sanawīyah, 2002, p. 38)

According to Shamir the legitimacy of Jordan derived from the fact that it was a Palestinian state. He told Lord Carrington, the architect of the UN 242 Resolution, which required Israel to withdraw from the Arab territories that it occupied in Six Day War, "As far as I am concerned, the national aspirations of the Palestinian people had already found their expression in Jordan" (Al-Dhikrá al-sanawīyah, 2002, p. 39). Ariel Sharon who emerged as a major figure in the Likud Party at that time held similar views.

He had repeatedly argued that King Hussein was the real threat to peace in the region and said that he would rather see PLO leader Yasser Arafat rule Jordan. Sharon's rationale was that converting King Hussein's kingdom from Jordan into Palestine would invalidate the Palestinian claim for another Palestinian state at Israel's expense. In one of his meetings with at the Knesset lounge in 1982, he went to the extent of saying that he was willing to help the Palestinians overthrow King Hussein and turn Jordan into a Palestinian state. Sharon's plan became more concrete in 1982, after Israel's war in Lebanon. He hoped that the destruction of the PLO's infrastructure in Lebanon would cause the Palestinians to leave the country. His rationale was that 
since Syria would allow them entry they would be forced to return to Jordan, overthrow the King and thereby by turn the Jordan -Palestine equation into reality (Netanyahu, 2000, pp. 41-42).

The hard-line policy of the Israeli right-wing continued and Benjamin Netanyahu who led the party since 1993 continues to regard Jordan as the homeland of the Palestinians. He writes:

For over the years, nearly all the refugees have been absorbed into the economies and societies of the countries of their residence. Indeed, most Palestinian Arabs have home. Many of them, in fact, live as full citizens in eastern Palestine today called the Hashemite Kingdom of Jordan. (Netanyahu, 2000, p. 156)

\section{The Palestinians and the Syrian factor}

From the early days of his country's existence as an independent state King Hussein's approach to Israel was accompanied by distance which he kept from the Palestinians. The existence of a large majority of Palestinians in his country made him fully aware that his regime was under threat. Reinforced by the insistence of the Israeli right-wing, the Jordan-Palestine equation was a major deterrent to him and he sought to neutralize or supplant the Palestinian struggle for sovereignty with a demand to restore the lost land to the Hashemite Kingdom of Jordan. And while he called Israel an aggressor who refused to withdraw from Arab land in return for peace he continued his secret meetings with the Israelis. Although he had publically identified with the Palestinians he never made a definite commitment to fight for them and his patience ran thin in in 1970, when they caused disorder that compelled him to use force, which ended in their eviction from the country. Perhaps there is some truth in the argument of Mohamed Hassanein Heikal, the celebrated editor of the Egyptian semi-official Al-Ahram that Nasser felt that King Hussein had underestimated the power of the Palestinian resistance (Heikal, 1973, p. 2). Nevertheless, by the fall of 1970 the King was convinced that they constituted s serious threat to his regime and the battle was joined.

Another way in which he attempted to reduce the influence of the Palestinians in his country is the previously mentioned method of relying on the support of the Bedouin tribes, which turned into the pillars of his regime, and he was partially successful in this endeavor. His efforts were geared to turning the East Bank into a separate area with a unique identity. The West Bank, which turned into a liability was gradually abandoned and although he never stated it clearly in public, the King did not oppose Israeli intervention in it. Clearly, there was a common ground between the King and the Israeli government who found the rise of the Palestinian nationalist movement irksome.

Following the King's crackdown on the Palestinians in 1970, Syria exploited the opportunity to invade the country and increase its influence there. Both Israel and Jordan were alarmed at that prospect. The King found it necessary to ask for Israeli assistance through Washington. Thereupon, Secretary of State Henry Kissinger called Yitzhak Rabin who was Israel's ambassador to Washington at that time saying, "King Hussein has approached us, describing the situation of his forces, and asked me to transmit his request that your air forces attack the Syrians in northern Jordan. I need an immediate reply" (Rabin, 1979, p. 187). Israel responded with alacrity and it was only after it stationed its forces in Irbid and the Golan Heights that the Jordanian army managed to stop the Syrian assault. Washington's reaction to the Syrian aggression was harsher than anyone expected: Assistant Secretary of State Joseph Sisco went to the extent of warning Yuli Vorontsov who was the chargé d'affaires at the Soviet embassy in Washington at that time, that a failure to put a stop to Syrian hostilities might result in a joint American-Israeli operation to come to Jordan's rescue (Rafael, 1981, pp. 245-246). Undoubtedly, this firm commitment from Washington and the Israeli troop concentration on the 
Syrian border brought the Israeli-Jordanian cooperation to a new height. Not only was the King confident that Israel would not allow a Syrian invasion of his territory to take place, but he also realized how valuable was Israel's influence in Washington and how much he benefited from it.

The 1970s brought Jordan and Israel to yet greater understanding. This was largely because the King realized that an alliance with Israel could greatly enhance the stability of his regime. This explains why in September 1973 he visited Israel secretly where he met Prime Minister Golda Meir and informed her of an imminent attack by the Arab states. The intensity of the domestic pressures in his country brought the King to intensify his efforts to cement the relations with Israel. The gains made by the PLO and the wider acceptance of the Palestinians by the international community were disquieting for the King. Despite international outrage and condemnation the commando raids and the airplane hijacking brought the Palestinian issue to world attention. Substantial gains were made by the Palestinians when the PLO obtained recognition from more countries throughout the world. The Arab summit meeting, which convened in Rabat in October 1974, granted the PLO the status of the sole representative of the Palestinian people. In the following month, PLO Chairman Yasser Arafat was invited to the address the UN where he delivered his famous "gun and olive branch" speech. Furthermore, in 1975, the PLO obtained an observer status at the UN, and the resolution equating Zionism with racism was adopted by the General Assembly. These developments were disquieting for King Hussein as well as for the Israelis. The King continued to disassociate himself from the Palestinians. Although he made references to Israeli obstinacy and reluctance to swap land for peace, his speeches had virtually no references to the Palestinians. Nor was he critical of the Israeli-Egyptian peace process, which began by Egyptian President Anwar Sadat's visit to the Knesset on November 19, 1977 and culminated in the Camp David according the following year.

The Islamic revolution, which brought Ayatollah Khomeini to power in Iran in 1979, was another source of concern for the two countries. Khomeini's rise brought to an end the long era of tacit cooperation between Israel and Shah Muhammad Reza Pahlavi. Neither the Israelis nor the King were delighted to see Arafat rush to greet Iran's new master. Furthermore, the prospects of closer relations between Syria and Iran increased the King's sense of isolation and his fear of another military encounter with Syria increased as well. Indeed, by 1980 tension along Jordan's border with Syria mounted again. The common concern brought Jordan and Israel to expand their military cooperation and Israel sent troops, which remained along the border until the crisis subsided.

The conclusion of the Camp David accord provided a further impetus to the Israeli-Jordanian peace process. Although it was denounced by most Arab states for signing a peace treaty with Israel, Egypt had crossed the psychological barrier, which had long prevented contacts between Arabs and Israelis and thereby encouraged the King to normalize his relations with Israel. In 1987, the Arab League members restored their diplomatic relations with Egypt, and in 1989 the League's headquarters was moved back to Cairo. This was a clear sign to King Hussein that the Arab wrath had its limits. Realizing that Egypt had already signed a peace treaty with Israel and that both the Palestinians and the Syrians were in a process of negotiating peace with Israel the King did not wish to be left alone and he moved ahead with the peace process.

The outbreak of the Palestinian Intifada in the West Bank in November 1987 brought the King to the realization that his regime was in serious danger and that caused him to fear that the "Jordan-Palestine" equation might after all become reality. He therefore decided to take the drastic step of renouncing all claims to the West Bank and thereby gave Israel freedom of action in the West Bank. This decision spelled a clear 
division of functions between the two countries; the King would rule the East Bank while Israel will control the West Bank.

By the late 1980s Israel managed to normalize relations with numerous countries in Asia and Africa. Major states such as India, China and Japan began establishing diplomatic relations with Israel. Such diplomatic triumphs gave Israel greater legitimacy, helped establish contacts with moderate Arab countries, and acted as a catalyst in the normalization process, encouraging the King to contact the Israelis more frequently and the expand the areas of cooperation. All along, economic considerations played a major role in the King's decision to move ahead with the normalization process. The paucity of the country's resources, the lack of adequate water supplies and the need for greater economic assistance from Washington convinced the King that Israel was the essential channel through which he could obtain increased financial aid. The end of the Cold War brought King Hussein to the realization that the United States was the only global power capable of supporting the tottering Jordanian economy. It was now worthwhile and far less risky for the King to reach the Israelis, open trade channels and thereby boost the economy. Aware of his weakness the King planned his strategy carefully. As Sharif Nashashibi of al-Jazeera put it, "Jordan knows it is militarily weak and economically poor in a turbulent region, so it has to perform delicate balancing acts to ensure its security by minimizing tensions with its neighbors. It knew it would gain more from a peace with Israel that did not require major concessions than from a continued state of war with a much more powerful adversary" (Nashashibi, 2014).

In the final analysis, it was the onset of the Israeli-Palestinian dialogue, which released the King from his hesitations. The King had come to the realization that Palestinians who constituted more than half of his population will not raise objection to normalization with Israel. The Israeli-Palestinian contacts that culminated in the Oslo accord of 1993, paved the way to the Wadi 'Araba agreement. The King had reluctantly accepted the Oslo accord. He was not consulted and was not informed about its details. Nevertheless, in the absence of any other alternative he accepted it as a basis for viable peace. He told Peter Hinchcliffe that this was the "only game in town". He then started planning the peace talks with Israel. This was an opportune moment since the hard line Likud Party was out of power in Israel. He was convinced that Labor Prime Minister Yitzhak Rabin would be a better partner for peace than any right-wing prime minister. Moreover, he was convinced that a treaty with Israel would provide a boost to the Jordanian economy, which suffered as a result of the international embargo on trade, which was imposed on Iraq in the wake of the Gulf War of 1991. Given the fact that Jordan lost much of the Iraqi market when the UN sanctions were imposed and the relationship with the Gulf countries went sour, there was little choice but to move ahead with the normalization process. Jordan needed to attract investment and to obtain more water. Peace could earn the King the good will of the Americans from whom he hoped to obtain F16 fighter planes for his air force. Moreover, King Hussein believed that the peace treaty with Israel would help him obtain Britain's promise to write off Jordan's loans and to provide credit to boost the economy. Above all, the King was confident that the treaty could bolster his claim to be the guardian of the holy sites in Jerusalem. Indeed, the treaty stated that Israel agreed to respect his special role as custodianship over the holy sites (Lapidoth, 2013).

There were clear signs that the King had long sought peace with Israel. His decision to stay out of the Yom Kippur War and his efforts to prevent Palestinian commando attacks from his territory were among the earliest and the most obvious ones. Peace was just a matter of time; the assassination of his grandfather and two Jordanian prime ministers who favored peace with Israel had only delayed the inevitable (Hertz, 2013). 


\section{Setting the Stage for Negotiations}

In order to suppress the opposition to the separate treaty, which he had planned to reach with Israel the King had to take a personal lead in the campaign and show the Jordanian public that this "was the King's peace" and that opposition to it would not be tolerated. In addition, he embarked on a campaign to convince the Jordanian public that peace with Israel was a necessity and that it provided an opportunity to bring to an end the isolation imposed on the country in the aftermath of the Gulf War. Sympathetic officials, both in the Foreign Affairs Committee and in the House of Representatives had portrayed the treaty as a most realistic and desirable step that Jordan ought to take, and they argued that Jordan had already obtained numerous concessions from Israel, including rights to land and water. Prime Minister 'Abd al-Salam al-Majali stated that by signing the treaty all outstanding issues with Israel were settled, that Jordan had obtained the territories previously held by Israel, and that it was about to gain access to more water both from the Jordan River and the Sea of Galilee. He stressed that Israel explicitly recognized the unique identity of the Jordanian state and agreed that Jordan was not Palestine. Commenting on this point the eminent writer Cecil Hourani said in his editorial to Jordan Times that the treaty put an end to the possibility that the Israeli government might revive that claim. Another prominent figure, 'Abd al-Hafiz al-Shakhanibah expressed a similar view in a speech to the House of Representatives (Scham \& Lucas, 2001, p. 58).

To silence those who opposed the treaty on the ground that it was signed by Jordan, without bringing the other Arab states into the fold, the government emphasized that Jordan was not the first Arab country to conclude a peace treaty with Israel, that the treaty would not be confined to Israeli-Jordanian issues but would include issues such as the future of the Palestinian refugees and economic cooperation, and that both the Palestinians and the Egyptians would take part in it. And last but not the least, the government emphasized the economic benefits which peace with Israel would bring, which included not only economic cooperation but also investments and employment opportunities, and most importantly, greater economic aid from the United States. In order to bolster its claim that the treaty would benefit the Jordanian economy the Hashemite regime emphasized the benefits which Egypt gained as a result of the Camp David accord.

Anticipating opposition by the members of the Muslim Brotherhood the King used his intelligence to monitor their activities. Strict measures were adopted by the police to salience the group's opposition to the treaty. Warnings, preempting arrests and other strict measures were imposed, including a ban on preaching (Nachman, 2005, p. 211). When Senior Hamas leaders in Jordan expressed their concern that the peace treaty with Israel would have adverse effect on their presence in the country the head of Jordan's intelligence department Mustafa al-Qaysi reassured them that they had nothing to worry about as long as they confined their activities to political and media-related matters (Tamimi, 2007, p. 80).

Opponents of the Wadi 'Araba peace accord argue that by establishing diplomatic relations with Israel the King ignored the popular anti-Israeli sentiment and made the effort to curtail the growing influence of the Islamists by purposely tampering with the electoral process. Thus for example, Azzam Tamimi argued that five years prior to the signing of the Wadi 'Araba Agreement, Jordan was in turmoil, that the government of Zaid al-Rifa'i adopted strict measures, which caused popular unrest in the south, and that the King continued to maintain clandestine contacts with the Israelis with a view to reach a peace accord with total disregard to the public sentiment. He argues that in April 1989, the King found it necessary to appease public opinion by introducing liberal measures and that to his dismay the elections brought victory to the Islamists. Subsequent 
events such as the Iraqi invasion of Kuwait in 1990, the Madrid Peace Conference of 1991 and the King's decision to reach an accord with Israel led to further disillusionment among the Jordanian public and especially the Palestinians among them. Concerned about the rising popularity of the Islamists the King reversed his liberalizing policy and closely monitored the legislative elections of November 1993 that weakened the Islamists (Tamimi, 2014).

In 1992, the King distanced himself from Saddam Hussein in an effort to improve his relations with Washington. With the help of the Israelis who lobbied on his behalf in Washington he managed to repair the damage that the Gulf War caused to Jordanian-American relations and on June 18, 1993 he met President Clinton at the White House. It is possible that his illness prompted him to conclude the treaty with Israel before his death. After he had been diagnosed with cancer in the summer of 1992, he returned home and was warmly received by his people. He said on that occasion, "I felt an element of fear-of insecurity —about what might happen if I was not there, so I knew that I had to do everything I could, in whatever time I had left, to achieve peace and make it work" (Miller, 1999). In October 1992, Jordan and Israeli agreed to conclude a formal peace treaty as part of a comprehensive Arab-Israeli settlement. And when the Oslo Accord between Israeli and the Palestinians was reached in the summer of 1993, he did not wish to be left out.

On September 3, 1993 Arafat informed King Hussein of his negotiations with Israel, which led to the Oslo Agreement. Although he felt that he was not informed about the process, the King supported the initiative. The following day he decided on the Israeli-Jordanian agenda for peace talks but he still insisted that he will not sign a treaty without Syria and Lebanon. When news regarding the Oslo Agreement circulated in Jordan the opposition groups, both the Leftists and the Islamists criticized it as a capitulation to the Zionist enemy. Prominent literary figures such as Muna Shuqir, Salah al-Qallab and others were highly critical of the agreement, while many of the Palestinians held demonstrations against it. Meanwhile, the King began preparing for the peace treaty by tampering with the electoral law. In preparation for the elections that were scheduled to take place in November 1993, an amendment was introduced on August 17, which replaced the "open list" system which gave the Muslim Brotherhood the electoral advantage with the "one-man, one vote" system, which benefited the tribal leaders who were the main supporters of the Hashemite regime. The opposition was forced to accept the measure as fait accompli. Consequently, the tribal leaders won a majority of seats and the opposition groups lost half of their seats. By these means the King managed to eliminate the opposition to the peace treaty (Scham \& Lucas, 2001, p. 57). He then met Foreign Minister Shimon Peres in Amman where they agreed to economic cooperation. Then In July 1994, he met Rabin in Washington and announced his decision to end the state of war with Israel. The formal peace treaty was signed on October 26, 1994 at Wadi 'Araba, on the Israeli-Jordanian border.

\section{Conclusion}

Despite the absence of a peace treaty, Israel and Jordan had maintained normal relations for at least two decades prior to its signature. According to press reports King Hussein met Israeli leaders in numerous locations, in the capitals of Europe, along the border and even in Israel itself. The long border which separated the two countries remained quiet since 1970, when the Palestinians guerrilla fighters left the country on their way to Lebanon. Confident that Jordan did not constitute a threat to its existence the Israeli government became accustomed to regard Jordan as its security buffer. This became abundantly clear during the Gulf War of 1990, when Jordan remained neutral. Israeli officials made it clear that Jordan's border with Iraq was Israel's line of 
defense in the east (Miller, 1999, p. 54). Hopes for formal peace with Jordan reached their apogee in 1993, when the PLO and Israel signed the Declaration of Principles. The Wadi 'Araba treaty confirmed the status quo and was universally accepted in Israel. With the exception of the Islamists and some Leftist groups the Jordanian public welcomed the peace treaty, and it was not until the optimism generated by Declaration of Principles faded that many began to criticize the treaty and called for its revocation. Yet despite the peaceful status quo and the absence of friction along the border the peace treaty had an element of surprise to many Israelis who never forgot that the Jordanian public openly sympathized with the Saddam Hussein during the Gulf War and that despite the absence of border clashes neither the Jordanian media nor its educational system abandoned their anti-Israel pronouncements. Despite the fact that many Jordanians referred to the treaty as an "alliance" significant part of the public remained either hostile to it or skeptical of its usefulness.

During the period between 1957 until 1992 and there were no opposition organs in Jordan, with the exception of the professional associations and the Muslim Brotherhood, which appeared under the name The Islamic Action Front when the parties made their reappearance in 1992. Opponents of the peace treaty with Israeli came both from Islamists and Leftists. These elements had long opposed any contact with Israel. At the same time, the attitude of the Jordanian public wavered according to the incidents that occurred following the conclusion of the peace accord such as Operation Grapes of Wrath that was carried out by the Israelis in April 1996 against the Hizballah in Lebanon, the opening of the Western Wall tunnel in September 1996, and the Israeli attempt on the life of Hamas leader Khalid Mashal in September 1997. In some cases the Jordanian public sympathized with the Israeli victims when the Palestinians were the perpetrators. Such was the case during Palestinian bombing of the Israeli buses in the spring of 1996, or when King Hussein visited the parents of an Israeli soldier who was killed in an act perpetrated by Palestinians in March 1997.

According to L. Scham and Russel E. Lucas the professional associations in Jordan were the main ones who led the campaign against the peace treaty. Shortly before the signing of the treaty these associations formed an "anti-normalization committee" which sought to expose all the contacts with Israel. This effort culminated in the publication of a "List of Shame" on the Internet, urging the Jordanian public to boycott companies who dealt with Israel. Even some of legislators urged the government to renounce the peace treaty (Miller, 1999, p. 55). However, despite its criticism of the treaty the opposition never denied the need to obtain peace. The Arab nationalists and the Leftists who criticized the treaty argued that it was a separate attempt that did not bring other parties to it and that it violated the Security Council's resolutions that dealt with the solution to the Arab-Israeli conflict. The Islamists among them emphasized the damage that the treaty caused to Jordan's ties with other Arab countries. Some of the opponents argued that the treaty violated the right of the Palestinian refugees to return to their homeland. Those critics argued that the treaty portrayed the issue as humanitarian rather than a political one. Then there were those who argued that by signing the treaty the government compromised its sovereignty over land and waters and not regained them as the government had claimed. And last but not the least, the manner by which the government coerced the public into accepting the treaty was highly criticized by the opposition. Those critics argued that the process of accommodation with Israel was accompanied by repressive measures, that demonstrations against the treaty were prohibited, and that the liberal trend which preceded the peace treaty was literally brought to an end. Paul Scham and Russell Lucas had quoted one of the critics, Labib Qamhawi as saying that "this period requires absolute obedience, and this is why democracy is a luxury that the government will not tolerate or accept" (Miller, 1999, p. 59). Indeed, the implementation of the treaty brought strict measures in its wake. Opposition was not tolerated and very few 
government officials were allowed to take part in the decision-making process. Generally, however, the opposition criticized the treaty peacefully and in a civil manner and there were no flagrant violations of the government's regulations.

The anti-Israeli sentiment persists, leaving the United States as the only power capable of silencing the opposition and convincing the Jordanians that the peace treaty was accompanied by considerable political and economic windfalls (Satloff \& Schenker, 2013). But one of the most devastating impacts of the peace treaty was the deterioration in Jordan's ties with Syria, which reached their nadir in the fall of 1998, when the Syrian press unleashed a barrage of accusations against Jordan and what it described as its treacherous collaboration with the Zionist entity. The recent civil war and the turmoil in Syria have reduced the pressure on the Jordanian government and despite the persistence of the opposition groups there seems no immediate threat to the peace treaty.

\section{References}

Ajami, F. (1992). The Arab Predicament: Arab political thought and practice since 1967. New York: Cambridge University Press.

Alon, Y. (2001). State-Tribe relations in Mandatory Transjordan: Tribes and state formation processes (Hebrew). Jama'a, 8(3), 84-115.

Al-Dhikrá al-sanawīyah al-ūlá li-rahīl fāris al-karāmah al-Farīq al-Rukn Mashhūr Hadītah al-Jāzi. (2002). 'Ammān: Matābi' al-Dustūr al-Tijāriyah.

Al-Tamīmī, Anwar al- Khātīb, (1989). Ma'a Salāḥ al-Din fì al-Quds: ta'ammulāt wa-dhikrayāt. Al-Quds: Dār al-Tibā'a al-'Arābīyah.

Bader, Y. (1979). The Knesset and I [Hebrew]. Jerusalem: Edanim.

Bligh, A. (1998). Jordanian-Israeli strategic partnership in historical perspective. ACPR (Ariel Center for Policy Research) Policy Paper No. 24.

Eban, A. (1977). An autobiography. New York: Random House.

Fatḥi, M. A. (2003). Misr min al-thawrah ila al-nāksāh: mūqadāmāt ḥarb ḥuzayrān yūnyū 1967. Abū Dhabi: Markaz al-Imārāt lil-dirāsāt wal būḥūth al-istratījīyyah.

Gelber, Y. (1997). Jewish Transjordanian relations 1921-1948. London: Frank Cass.

Heikal, M. H. (1973). The Cairo Documents: The inside story of Nasser and his relationships with world leaders, rebels and statesmen. Garden City, New York: Doubleday \& Company.

Hertz, E. E. (2013). Arab-Israeli peace agreements. Retrieved from http://www.mythsandfacts.org.media/user/PLO-Agreement. pdf

Kimche, D. (1991). The last option: After Nasser, Arafat \& Hussein: The quest for peace in the Middle East. London: Weidenfeld and Nicolson.

Lapidoth, R. (2013). A recent agreement on the holy places in Jerusalem. Retrieved from http://www.israelcfr.com/documents/

7-3/7-3-5- RuthLapidoth.pdf

Lyndon Johnson Administration: Memorandum on Hussein Letter Revealing Secret Meetings with Israel. (1966, December 12). Retrieved from http://www.jewishvirtual library.org/jsource/USIsrael/FRUS12_12_66. Html

Mādhā taraka al-amīr lil-asatīr. (1938). Ammān?: Maktab al-Di'āyah wa-al-Nashr lil Qadhīyah al-Urdunīyah.

Mitha, F. (2010). The Jordanian-Israeli relationship: The reality of "cooperation". Middle East Policy, 17(2), 105-126.

Medzini, M. (1990). The proud Jewess: Golda Meir and the vision of Israel: A political biography [Hebrew]. Tel Aviv: Edanim.

Miller, J. (1999). Death of a King: Cautious King took risks in straddling two worlds. The New York Times, February 8. Retrieved from http://www.nytimes.com/learning/general/onthisday/bday/1114.html

Nachman, T. (2005). Radical Islam in Egypt and Jordan. Brighton, UK: Sussex Academic Press.

Nashashibi, S. (2014). Why peace with Israel was good for Jordan. Al-Jazeera. Retrieved from http://www.aljazeera.com/indepth/ opinion/2014/10/why-peace-with-israel-was-good--201410265360338272.html

Naor, A. (1988). Writing of the wall: Where is the Likud leading to? [Hebrew]. Tel Aviv: Edanim.

Oren, M. B. (2002). Six days of war: June 1967 and the making of the modern Middle East. Oxford, UK: Oxford University Press. 
Peres, S., \& Eshed, H. (1978). Tomorrow is now (Hebrew). Jerusalem: Keter.

Rafael, G. (1981). Three decades of Israeli foreign policy-a personal memoir. New York: Stein And Day.

Rabin, Y. (1979). The Rabin Memoirs. Boston: Little Brown and Company.

Satloff, R., \& Schenker, D. (2013). Political instability in Jordan: Contingency planning Memorandum No. 19. Council on Foreign Relations Press. Retrieved from http://www.cfr.org/jordan/political-instability-jordan/p30698

Scham, P. L., \& Lucas, R. E. (2001). "Normalization” and “anti-normalization” in Jordan: The public debate. MERIA (Middle East Review of International Affairs, 5(3), 54-70.

Sharett, M. (1978). Yoman Ishī (Personal Diary), Vol. II. (Hebrew). Tel Aviv: Sifriyat Ma'ariv.

Tamimi, A. (2007). Hamas: A history from within. Northampton, Massachusetts: Olive Branch Press.

Tamimi, A. (2014). Why peace with Israel was bad for Jordan. Retrieved from http://www.aljazeera.com/indepth/opinion/ 2014/10/why-peace-with-israel-was-bad--2014102654832952355.html

Yergin, D. (1992). The prize: The epic quest for oil money \& power. New York: Touchstone.

Zaki, S. (2007). Diplomacy in the shadow of war: Myth and reality in advance of the Six Day War (Hebrew). Tel-Aviv: Ministry of Defense Publishing House. 